\title{
PHYSICOCHEMICAL, HISTOLOGICAL AND ORGANOLEPTIC EVALUATION OF RED-SOKOTO (MARADI) BUCK MEAT AS AFFECTED BY CARCASS DRESSING METHODS
}

\author{
Ebunoluwa Stanley Apata ${ }^{1}$, Andrew Babatunde Omojola ${ }^{2}$, Olusey Omoniyi Eniolorunda ${ }^{1}$, \\ Elizabeth Omokoshi Joel ${ }^{2}$ \\ ${ }^{1}$ Meat Science Laboratory, Department of Animal Production, Olabisi Onabanjo University, \\ Ayetoro Campus, PMB 0012 Ayetoro, Ogun State, Nigeria \\ ${ }^{2}$ Department of Animal Science, University of Ibadan, Ibadan, Oyo State, Nigeria \\ ebunoluapata2008@yahoo.com
}

\begin{abstract}
A b s t r a c t: This study was carried out to investigate the effect of carcass dressing methods on physical, chemical, histological and sensory characteristics of Red-Sokoto buck meat. Nine buck were purchased, stabilized on a standard feed for 2 weeks, fasted for 16 hours, stunned and slaughtered and their carcasses were randomly allotted to three dressing methods: scalding, skinning and singeing. The carcasses were eviscerated, dressed, chilled and fabricated. Carcass characteristics primal cuts yield, sercomene length and fibre diameters were determined, while physicochemical and sensory attributes were evaluated from meat sample excised from thigh cut. The results showed that, scalding furnished higher $(p<0.05)$ values for carcass weight yield and rib eye area, but skining elicited high $(p<0.05)$ carcass and muscles dimensions, cooking yield, water holding capacity, while singeing gave higher $(p<0.05)$ meat colour, protein content, eating proper diets and acceptability. Since scalding furnished high yield, and skinning elicited keeping quality while singeing gave eating properties and acceptability, it is therefore recommended that processors should adopt scalding for high yield for high profitability, retailers of goat meat take to skinning method for proper keeping of meat, while the meat products processors should utilize singeing for high eating quality and acceptability.
\end{abstract}

Key words: buckmeat; dressing methods; histological; organoleptic; physicochemical; Red-Sokoto

\section{ФИЗИЧКО-ХЕМИСКО, ХИСТОЛОШКО И ОРГАНОЛЕПТИЧКО ОЦЕНУВАЊЕ НА МЕСО ОД ЈАРЕЦ RED-SOKОTO (MARADI) ВО ОДНОС НА МЕТОДИТЕ ЗА ОБРАБОТКА НА ТРУПОТ}

А п с т р а к т: Оваа студија беше спроведена за да се испита влијанието на методите за обработка на трупот врз физичките, хемиските, хистолошките и сензорните карактеристики на месо од јарец - Red-Sokoto (Maradi). Беа купени девет животни, стабилизирани на стандардна сточна храна во текот на 2 недели, гладуваа 16 часа, потоа беа зашеметени и заклани, а нивните трупови беа земени по случаен избор за понатамошна постапка со три методи на обработка: шурење, отстранување на кожата (дерење) и опрлување. Од труповите беа отстранети внатрешните органи, беа обработени, оладени и подготвени за пазар. Карактеристиките на трупот, рандманот, должината на саркомер и дијаметарот на влакната беа одредувани на трупот, додека физичкохемиските и сензорните својства беа оценувани кај примероци месо исечено од бутот. Резултатите покажаа дека шурењето дава повисоки вредности $(p<0,05)$ за рандманот на трупот и пределот на ребреното око, но отстранувањето на кожата придонесува за големи димензии на трупот и мускулите со висока сигнификантност $(p<0.05)$, поголема количина при готвење, одржливост на капацитетот за содржина на вода, додека опрлувањето дава повисоки вредности за бојата на месото и, содржината на протеини, добра јадливост и прифатливост. Со оглед на тоа што шурењето обезбедува висок принос, дерењето е подобро за одржување на квалитетот, а опрлувањето дава подобри својства за јадење и прифатливост, се препорачува преработувачите да го прифатат шурењето за висок принос и повисока профитабилност, трговците на мало да го применуваат методот на дерење за правилно чување на месото, додека преработувачите на производи од месо треба да го употребуваат опрлувањето за висок квалитет на јадливоста и прифатливоста.

Клучни зборови: месо од јарец; методи на обработка; хистолошки; органолептички; физичко-хемиски; Red-Sokoto 


\section{INTRODUCTION}

Meat production, processing and consumption are of tremendous economic, social and ecological importance. This is because meat is a very rich source of high quality food nutrients that is protein, vitamins and minerals as well as fatty acids needed by humans for growth and maintenance of good health (McMillan and Brock, 2005). Goat meat (chevon) is a source of animal protein that is available to the increasing meat consumers in different forms (Egbunike and Okubanjo, 1999) and the production is been intensified until recently when the major concern is that of quality of the meat consumed (Insausti et al., 2001). Meat quality is been regarded as generic term used to describe properties and perception of meat attributes such as carcass composition, configuration and eating properties (Maltin et al., 2003). It had been reported that the nutriional and eating qualities of meat are influenced by various factors most especially ante and post-mortem factors (Omojola and Adesehinwa, 2006). Ante-mortem factors involve animals' health condition and stress while, the postmortem factors include carcass processing biochemical changes that occur in meat post-slaughter, storage and distribution chain (Keith et al., 2002). The pre-slaughter or ante-mortem factors can be controlled to an extent, but the post-slaughter conditions still need to be understood since there are great variability in post-slaughter conditions that affect meat quality (Okubanjo et al., 2003). But Omojola and Adesehinwa (2006) reported that paramount among the post-slaughter processing of animal carcasses, known to affect notable characteristics of meat in the dressing method employed which can be either scalding, skinning or singeing as the case maybe which are used for small stocks like sheep and goats and recently for cattle carcasses. The aim of this study is, therefore, to determine the effect of post-slaughter dressing methods on meat characterristics such as physical, chemical, histological and sensory attributes.

\section{MATERIALS AND METHODS}

Nine Red-Sokoto bucks of age between 10 and 12 months old, $18-20 \mathrm{~kg}$, were used for this study. They were purchased from Bodija Market at Ibadan, Oyo State, and transported to the Department of Animal Science, University of Ibadan, where the study was conducted. The animals were quarantined, stabilized for two weeks on a standard diet.

\section{Slaughtering of animals}

The animals were fasted for 16 hours with access to clean water and their fasted weight taken and stunned and slaughtered in batches of 3 every other day. The animals were bled and their carcasses randomly allocated into three post-slaughter processing (dressing) of scalding, skinning and singeing (Omojola and Adesehinwa, 2006).

\section{Carcass processing}

Scalding of the carcasses was done by modifying the method prescribed by Monin et al., (1995). Hot water $\left(70^{\circ} \mathrm{C}\right)$ was poured on each carcass to soften the hairs which were scraped off the carcass with a metal scrapper.

Skinning was done by removing the skin completely off the carcasses with a sharp knife according to Omojola and Adesehinwa (2006).

Singeing was carried out by flaming off the hairsor the carcass over fire $\left(250^{\circ} \mathrm{C}\right)$ made with hard wood (Teak wood, Tectona grandis) until all the hairs were carefully burnt with minimal damage to the skin according to Okubanjo (1997).

\section{Carcass evisceration, chilling, fabrication, measure}

The carcasses were cut open, the external and internal organs were removed, the carcasses were washed and chilled at $4^{\circ} \mathrm{C}$ for 24 hours. The chilling weights were recorded and the carcasses fabricated into primal cuts (Okubanjo, 1997). Carcass length, lengths of legs and breath, depth of chest and rib eye area were measured according to Attah, (1997), while carcass and primal cuts yield were taken as described by Aduku and Olukosi (2000).

\section{Meat characteristics}

\section{Physical characteristics}

Fresh meat colour was determined with visual method described by AMSA (2012). Visual colour scores were determined based on colour intensity and homogeneity using a scale ranging from 1 to 8 with higher scores representing a more attractive and homogenous red colour.

Meat marbling was determined at the rib eye based on the subjective scores described by USDA (1997), on the scale ranging from 1 to 10 , where 1 corresponded to devoid and 10 to abundant.

Specific gravity of carcass leg was determined following the procedures of Maiga (1974) and Attah (1997). 


\section{Cooking loss and yield}

Cooking loss was determined according to Malgorzata et al, (2005) procedures, while cooking yield was determined following the procedures of Okubanjo (1997).

\section{Thermal and cold shortening}

Thermal shortening of meat samples was determined with the method of Apata (2011) while cold shortening was determined according to the procedures of Lawrie and Ledwards (2006).

\section{Drip and cold loss}

Drip loss of meat samples was determined following the procedures of Insausti et al, (2001) and cold loss determined according to Lawrie and Ledwards (2006).

\section{Water holding capacity (WHC) and shearforce}

Water holding capacity of meat samples was determined following the method described by Mallikarjuaman and Mittal 1994, while the shearforce was determined according to Malgorzata et al. (2005) and Qiaofen and Da-Wen (2005).

\section{Proximate composition and $\mathrm{pH}$ of meat}

The proximate composition of meat samples was determined according to AOAC (2000) procedures, while the $\mathrm{pH}$ was determined following the method of Marchiori and De Felicio (2003).

\section{Sarcomere and fibre diameters of muscle samples}

The sarcomere and fibre diameters of meat samples were determined using the modified method of Koohmariae (1996). Meat samples were fixed in $5 \%$ solution of glutaldehyde in $0.1 \mathrm{M} \mathrm{Na}-$ $\mathrm{HPO}_{4}$ buffer at $\mathrm{pH} 7.2$ at $4^{\circ} \mathrm{C}$. The glutaldehyde solution was replaced with 0.2 sucrose solution in $0.1 \mathrm{M} \mathrm{NaHPO}_{4}$ buffer at the same $\mathrm{pH}$ after 4 hours. The meat samples were teased and placed on a glass miscroscope side and were immersed in a drop of sucrose solution. The beam of calibrated Olypus microscope (Model 210-230) with magnification 1,000 was passed through the muscle fibres. Sarcomere lengths of muscle fibres were read off from the distance between the first and last bands, while fibre diameters were determined by taking the distances across the fibres at three different locations and the average obtained.

\section{Sensory evaluation of meat}

Sensory evaluation of meat samples was conducted following the procedures of AMSA (2015). A 10-member semi-trained taste panel was used. The taste panelists were drawn from students and workers in the Department of Animal Science, University of Ibadan. They were provided with unsalted biscuits and water for use in between treatment samples. The meat samples were coded after cooking for 20 minutes to an internal temperature of $72^{\circ} \mathrm{C}$ (Moist cooking). The meat samples were evaluated on 9-point hedonic scale for cooked meat colour, flavour, tenderness, juiciness, texture and overall acceptability on which scale $1=$ disliked extremely and $9=$ liked extremely.

\section{Experimental design and statistical analysis}

This study was conducted using completely randomized design, the data collected were analyzed using SAS (2002), while the significant means were separated with Duncan multiple range test of the same software at $p<0.05$.

\section{RESULTS}

\section{Carcass characteristics}

The results of carcass characteristics of buck goat are shown on Table 1. There was no significant $(p<0.05)$ difference in the fasted weights of live goats and depth of chest but there were differences $(p<0.05)$ in other characteristics of the carcasses with skinned carcasses having higher $(p<0.05)$ values than scalded and singed carcasses, while scalded and skinned carcasses had similar but higher $(p<$ $0.05)$ rib eye areas value and singed carcass the least $(p>0.05)$.

\section{Table 1}

Carcass characteristics of buck goat as affected by different dressing

\begin{tabular}{|c|c|c|c|}
\hline \multirow[b]{2}{*}{ Variable } & \multicolumn{3}{|c|}{ Treatments } \\
\hline & $\begin{array}{c}\text { T1 } \\
\text { Scalding }\end{array}$ & $\begin{array}{c}\text { T2 } \\
\text { Skinning }\end{array}$ & $\begin{array}{c}\text { T3 } \\
\text { Singeing }\end{array}$ \\
\hline Fasted weight (kg) & $17.51 \pm 0.01$ & $17.83 \pm 0.03$ & $17.07 \pm 0.03$ \\
\hline $\begin{array}{l}\text { Hot carcass weight } \\
(\mathrm{kg})\end{array}$ & $10.20 \pm 0.02^{\mathrm{a}}$ & $8.25 \pm 0.02^{c}$ & $9.40 \pm 0.02^{\mathrm{b}}$ \\
\hline $\begin{array}{l}\text { Chilled carcass } \\
\text { weight }(\mathrm{kg})\end{array}$ & $10.18 \pm 0.02^{\mathrm{a}}$ & $8.20 \pm 0.02^{c}$ & $9.37 \pm 0.03^{b}$ \\
\hline Chilling loss (\%) & $0.24 \pm 0.06^{\mathrm{c}}$ & $0.61 \pm 0.01^{\mathrm{a}}$ & $0.32 \pm 0.01^{b}$ \\
\hline Carcass length $(\mathrm{cm})$ & $42.61 \pm 0.01^{\mathrm{b}}$ & $44.74 \pm 0.02^{\mathrm{a}}$ & $34.33 \pm 0.02^{c}$ \\
\hline Length of leg $(\mathrm{cm})$ & $29.32 \pm 0.02^{b}$ & $34.07 \pm 0.06^{\mathrm{a}}$ & $25.14 \pm 0.04^{c}$ \\
\hline Breadth of leg $(\mathrm{cm})$ & $12.51 \pm 0.01^{b}$ & $14.31 \pm 0.01^{\mathrm{a}}$ & $10.22 \pm 0.02^{c}$ \\
\hline Depth of chest $(\mathrm{cm})$ & $15.43 \pm 0.02$ & $15.85 \pm 0.02$ & $15.24 \pm 0.01$ \\
\hline Rib eye area $\left(\mathrm{cm}^{2}\right)$ & $53.45 \pm 0.03^{\mathrm{a}}$ & $53.31 \pm 0.02^{\mathrm{a}}$ & $52.25 \pm 0.05^{b}$ \\
\hline
\end{tabular}




\section{Carcass and primal cuts yield}

Table 2 presents the results of the yield of carcasses and the primal cuts of bucks. The yield was higher and similar $(p>0.05)$ for scalded and singed carcasses and lower $(p<0.05)$ in skinned carcasses. The yield values were higher $(p<0.05)$ in the primal cuts of scalded carcasses followed by the primal cuts from singed carcasses, while those of skinned carcasses were the least $(p<0.05)$.

\section{Table 2}

Yield of carcasses and primal cuts of buck goat dressed differently

\begin{tabular}{|c|c|c|c|}
\hline \multirow[b]{2}{*}{$\begin{array}{l}\text { Variable } \\
(\%)\end{array}$} & \multicolumn{3}{|c|}{ Treatments } \\
\hline & $\begin{array}{c}\text { T1 } \\
\text { Scalding }\end{array}$ & $\begin{array}{c}\text { T2 } \\
\text { Skinning }\end{array}$ & $\begin{array}{c}\mathrm{T} 3 \\
\text { Singeing }\end{array}$ \\
\hline Carcass & $58.25 \pm 0.05^{\mathrm{a}}$ & $46.28 \pm 0.05^{c}$ & $53.20 \pm 0.03^{b}$ \\
\hline Thigh & $9.26 \pm 0.03^{\mathrm{a}}$ & $6.41 \pm 0.02^{c}$ & $8.19 \pm 0.02^{b}$ \\
\hline Loin & $6.37 \pm 0.02^{\mathrm{a}}$ & $4.93 \pm 0.02^{c}$ & $5.33 \pm 0.03^{b}$ \\
\hline Rack & $4.51 \pm 0.01^{\mathrm{a}}$ & $2.91 \pm 0.01^{\mathrm{c}}$ & $3.82 \pm 0.03^{b}$ \\
\hline Shoulder & $8.92 \pm 0.01^{\mathrm{a}}$ & $6.31 \pm 0.01^{\mathrm{c}}$ & $7.98 \pm 0.01^{b}$ \\
\hline Flank & $2.75 \pm 0.01^{\mathrm{a}}$ & $1.27 \pm 0.03^{b}$ & $2.35 \pm 0.02^{\mathrm{a}}$ \\
\hline Neck & $3.72 \pm 0.01^{\mathrm{a}}$ & $1.76 \pm 0.01^{\mathrm{c}}$ & $2.93 \pm 0.02^{\mathrm{b}}$ \\
\hline
\end{tabular}

\section{Physical characteristics of buck meat}

The results of physical characteristics of buck meat were presented on Table 3 . Fresh meat colour was higher $(p<0.05)$ in singed meat, while specific gravity, cooking yield and water holding capacity were higher $(p<0.05)$ in skinned meat also cooking loss, thermal shortening, drip loss, cold loss and shortening as well as shearforce values were lower $(p<0.05)$ than in singed and scalded meat.

\section{Proximate composition and $\mathrm{pH}$ of buck meat}

The results of the proximate composition and $\mathrm{pH}$ of buck meat as affected by dressing methods are shown on Table 4 . The skinned meat furnished the highest $(p<0.05)$ moisture content and singed meat the least $(p<0.05)$, while singed meat elicited the highest $(p<0.05)$ protein and scalded meat had the highest $(p<0.05)$ fat content. There was no significant difference in the values of $\mathrm{pH}$ in the meat samples across the 3 treatments, but the nitrogen free extract was higher $(p<0.05)$ in singed meat.
Table 3

Physical characteristic of buck goat meat as influenced by different dressing

\begin{tabular}{|c|c|c|c|}
\hline \multirow[b]{2}{*}{ Variable } & \multicolumn{3}{|c|}{ Treatments } \\
\hline & $\begin{array}{c}\mathrm{T} 1 \\
\text { Scalding }\end{array}$ & $\begin{array}{c}\mathrm{T} 2 \\
\text { Skinning }\end{array}$ & $\begin{array}{c}\mathrm{T} 3 \mid \\
\text { Singeing }\end{array}$ \\
\hline Fresh meat colour & $6.00 \pm 0.01^{\mathrm{b}}$ & $5.00 \pm 0.02^{c}$ & $7.00 \pm 0.02^{\mathrm{a}}$ \\
\hline Marbling & $6.47 \pm 0.01^{\mathrm{a}}$ & $4.25 \pm 0.05^{\mathrm{c}}$ & $5.27 \pm 0.02^{\mathrm{b}}$ \\
\hline Specific gravity & $1.25 \pm 0.02^{\mathrm{b}}$ & $2.47 \pm 0.02^{\mathrm{a}}$ & $1.40 \pm 0.02^{\mathrm{b}}$ \\
\hline Cooking loss $(\%)$ & $14.86 \pm 0.02^{\mathrm{b}}$ & $12.71 \pm 0.04^{\mathrm{c}}$ & $16.92 \pm 0.02^{\mathrm{a}}$ \\
\hline Cooking yield (\%) & $85.14 \pm 0.03^{\mathrm{b}}$ & $87.29 \pm 0.01^{\mathrm{a}}$ & $83.08 \pm 0.04^{c}$ \\
\hline Therm. shortening (\%) & $11.43 \pm 0.05^{\mathrm{b}}$ & $10.21 \pm 0.06^{c}$ & $12.55 \pm 0.02^{\mathrm{a}}$ \\
\hline Drip loss (\%) & $5.57 \pm 0.03^{\mathrm{b}}$ & $4.30 \pm 0.05^{\mathrm{c}}$ & $6.82 \pm 0.01^{\mathrm{a}}$ \\
\hline Cold loss $(\%)$ & $12.35 \pm 0.04^{\mathrm{b}}$ & $10.25 \pm 0.05^{\mathrm{c}}$ & $13.47 \pm 0.03^{\mathrm{a}}$ \\
\hline Cold shortening (\%) & $10.26 \pm 0.03^{\mathrm{b}}$ & $8.27 \pm 0.06^{\mathrm{c}}$ & $11.58 \pm 0.04^{\mathrm{a}}$ \\
\hline WHC $(\%)$ & $62.17 \pm 0.03^{\mathrm{b}}$ & $68.76 \pm 0.01^{\mathrm{a}}$ & $53.45 \pm 0.05^{c}$ \\
\hline Shear force $\left(\mathrm{kg} / \mathrm{cm}^{3}\right)$ & $5.20 \pm 0.02^{\mathrm{b}}$ & $4.12 \pm 0.06^{\mathrm{c}}$ & $6.28 \pm 0.02^{\mathrm{a}}$ \\
\hline
\end{tabular}

\section{Table 4}

Proximate composition and $\mathrm{pH}$ of goat meat as influenced by different dressing

\begin{tabular}{|c|c|c|c|}
\hline \multirow[b]{2}{*}{ Variable } & \multicolumn{3}{|c|}{ Treatments } \\
\hline & $\begin{array}{c}\text { T1 } \\
\text { Scalding }\end{array}$ & $\begin{array}{c}\text { T2 } \\
\text { Skinning }\end{array}$ & $\begin{array}{c}\mathrm{T} 3 \\
\text { Singeing }\end{array}$ \\
\hline Moisture (\%) & $66.25 \pm 0.01^{\mathrm{b}}$ & $68.20 \pm 0.02^{\mathrm{a}}$ & $57.32 \pm 0.03^{\mathrm{c}}$ \\
\hline Crude protein $(\%)$ & $19.60 \pm 0.02^{\mathrm{b}}$ & $18.52 \pm 0.04^{\mathrm{c}}$ & $21.45 \pm 0.01^{\mathrm{a}}$ \\
\hline Ether extract (\%) & $3.23 \pm 0.03^{\mathrm{a}}$ & $1.16 \pm 0.06^{c}$ & $2.20 \pm 0.05^{\mathrm{b}}$ \\
\hline Ash (\%) & $1.50 \pm 0.05$ & $1.42 \pm 0.06$ & $1.60 \pm 0.04$ \\
\hline $\operatorname{NFE}(\%)$ & $9.42 \pm 0.10^{\mathrm{c}}$ & $10.70 \pm 0.08^{\mathrm{b}}$ & $16.43 \pm 0.07^{\mathrm{a}}$ \\
\hline $\mathrm{pH}$ & $5.62 \pm 0.03$ & $5.54 \pm 0.02$ & $5.70 \pm 0.01$ \\
\hline
\end{tabular}

${ }^{a}, b, c$ Means on the same row with different superscripts are statistically significant $(\mathrm{p}<0.05)$.

$\mathrm{NFE}=$ Nitrogen free extract

\section{Sarcomere length of buck meat}

The results of sarcomere length of buck meat as influenced by scalding, skinning and singeing are shown on Table 5. The skinned meat furnished the highest $(p<0.05)$ sarcomere length values followed by meat samples from scalded carcasses and the least $(p<0.05)$ in meat samples from singed carcasses. 
Table 5

Sarcomere length of buck goat muscle as affected by different dressing

\begin{tabular}{lccc}
\hline \hline Variable & \multicolumn{3}{c}{ Treatments } \\
& $\begin{array}{c}\text { T1 } \\
\text { Scalding }\end{array}$ & $\begin{array}{c}\text { T2 } \\
\text { Skinning }\end{array}$ & $\begin{array}{c}\text { T3 } \\
\text { Singeing }\end{array}$ \\
\hline Thigh $(\mu \mathrm{m})$ & $1.71 \pm 0.03^{\mathrm{b}}$ & $2.73 \pm 0.01^{\mathrm{a}}$ & $0.70 \pm 0.05^{\mathrm{c}}$ \\
Loin $(\mu \mathrm{m})$ & $1.84 \pm 0.04^{\mathrm{b}}$ & $2.86 \pm 0.02^{\mathrm{a}}$ & $0.82 \pm 0.06^{\mathrm{c}}$ \\
Rack $(\mu \mathrm{m})$ & $1.55 \pm 0.05^{\mathrm{b}}$ & $2.58 \pm 0.04^{\mathrm{a}}$ & $0.53 \pm 0.09^{\mathrm{c}}$ \\
Shoulder $(\mu \mathrm{m})$ & $1.73 \pm 0.03^{\mathrm{b}}$ & $2.75 \pm 0.01^{\mathrm{a}}$ & $0.65 \pm 0.05^{\mathrm{c}}$ \\
Flank $(\mu \mathrm{m})$ & $1.61 \pm 0.05^{\mathrm{b}}$ & $2.67 \pm 0.05^{\mathrm{a}}$ & $0.58 \pm 0.08^{\mathrm{c}}$ \\
Neck $(\mu \mathrm{m})$ & $1.32 \pm 0.07^{\mathrm{b}}$ & $2.37 \pm 0.03^{\mathrm{a}}$ & $0.36 \pm 0.10^{\mathrm{c}}$ \\
\hline \hline
\end{tabular}

${ }_{\mathrm{a}, \mathrm{b}, \mathrm{c}}$ Means on the same row with different superscripts are statistically significant $(p<0.05)$.

\section{Fibre diameter of buck meat}

The fibre diameter values were higher $(p<0.05)$ in meat samples from skinned carcasses followed by those from scalded carcasses and those from singed carcasses elicited the lowest $(p<0.05)$ fibre diameters.

Table 6

Fiber diameter of buck goat muscle as influenced by different dressing.

\begin{tabular}{lccc}
\hline \hline & \multicolumn{3}{c}{ Treatments } \\
\cline { 2 - 4 } Variable & $\begin{array}{c}\text { T1 } \\
\text { Scalding }\end{array}$ & $\begin{array}{c}\text { T2 } \\
\text { Skinning }\end{array}$ & $\begin{array}{c}\text { T3 } \\
\text { Singeing }\end{array}$ \\
\hline Thigh $(\mu \mathrm{m})$ & $65.73 \pm 0.03^{\mathrm{b}}$ & $73.41 \pm 0.01^{\mathrm{a}}$ & $52.93 \pm 0.05^{\mathrm{c}}$ \\
Loin $(\mu \mathrm{m})$ & $68.27 \pm 0.02^{\mathrm{b}}$ & $76.53 \pm 0.01^{\mathrm{a}}$ & $56.48 \pm 0.03^{\mathrm{c}}$ \\
Rack $(\mu \mathrm{m})$ & $62.08 \pm 0.04^{\mathrm{b}}$ & $70.12 \pm 0.02^{\mathrm{a}}$ & $50.64 \pm 0.06^{\mathrm{c}}$ \\
Shoulder $(\mu \mathrm{m})$ & $64.15 \pm 0.03^{\mathrm{b}}$ & $71.50 \pm 0.01^{\mathrm{a}}$ & $53.81 \pm 0.04^{\mathrm{c}}$ \\
Flank $(\mu \mathrm{m})$ & $62.81 \pm 0.04^{\mathrm{b}}$ & $70.74 \pm 0.02^{\mathrm{a}}$ & $51.23 \pm 0.06^{\mathrm{c}}$ \\
\hline Neck $(\mu \mathrm{m})$ & $57.88 \pm 0.05^{\mathrm{b}}$ & $69.82 \pm 0.02^{\mathrm{a}}$ & $48.31 \pm 0.07^{\mathrm{c}}$ \\
\hline \hline
\end{tabular}

a, b, c Means on the same row with different superscripts are statistically significant $(p<0.05)$

\section{Sensory evaluation of buck meat}

The results of the sensory evaluation of meat samples from scalded, skinned and singed carcasses are presented on Table 7 . All the sensory attributes except the meat texture were higher $(p<0.05)$ in meat samples from singed carcasses, meat texture was the highest $(p<0.05)$ in skinned meat, tenderness, juiciness, and acceptability scores were lower $(p<0.05)$ in skinned meat, while flavour was lower $(p<0.05)$ in scalded meat.

Table 7

Organoleptic scores goat meat as affected by different dressing

\begin{tabular}{lccc}
\hline \hline \multirow{2}{*}{ Variable } & \multicolumn{3}{c}{ Treatments } \\
\cline { 2 - 4 } & $\begin{array}{c}\text { T1 } \\
\text { Scalding }\end{array}$ & $\begin{array}{c}\text { T2 } \\
\text { Skinning }\end{array}$ & $\begin{array}{c}\text { T3 } \\
\text { Singeing }\end{array}$ \\
\hline Cooked meat colour & $6.52 \pm 0.02^{\mathrm{b}}$ & $5.33 \pm 0.03^{\mathrm{c}}$ & $6.65 \pm 0.01^{\mathrm{a}}$ \\
Flavour & $5.37 \pm 0.05^{\mathrm{c}}$ & $6.65 \pm 0.02^{\mathrm{b}}$ & $7.69 \pm 0.01^{\mathrm{a}}$ \\
Tenderness & $5.31 \pm 0.03^{\mathrm{b}}$ & $4.27 \pm 0.01^{\mathrm{c}}$ & $6.54 \pm 0.05^{\mathrm{a}}$ \\
Juiciness & $5.36 \pm 0.03^{\mathrm{b}}$ & $4.33 \pm 0.01^{\mathrm{c}}$ & $6.52 \pm 0.05^{\mathrm{a}}$ \\
Texture & $5.33 \pm 0.03^{\mathrm{b}}$ & $6.73 \pm 0.01^{\mathrm{a}}$ & $5.27 \pm 0.06^{\mathrm{b}}$ \\
OA & $6.56 \pm 0.02^{\mathrm{b}}$ & $5.34 \pm 0.02^{\mathrm{c}}$ & $7.61 \pm 0.01^{\mathrm{a}}$ \\
\hline \hline
\end{tabular}

a, b, c Means on the same row with different superscripts are

statistically significant $(p<0.05)$.

$\mathrm{OA}=$ Overall acceptability

\section{DISCUSSION}

\section{Carcass characteristics}

The results of carcass characteristics indicated that hot carcass weight was the highest in scalding and singeing. The lower weight recorded for singed carcasses could emanate from loss of fluids from the carcasses and some damage to the skin during flaming process, also lower weight was observed in skinned carcasses which could be due to complete removal of skin and most subcutaneous fat as well as the messentric fats that could have added to the weight of carcasses in this group. In the same vein scalded and singed carcasses could not loose much fluids during chilling probably due to the skin cover that might have shielded most of the fluid from draining, also scalded carcasses might have retained some of the poured water during scalding dressing and could have added to the weight of the carcasses against singed and skinned carcasses. The skinned carcasses because of lack of cover by skin were exposed to greater evaporative losses (Okubanjo 1997). However, skinned carcasses showed superiority over scalded and singed carcasses length and breath wise in their measurement due to the fact that there was probably no tempering effect of the axial skeleton on the contraction in the longissimus muscle mass and perhaps the fibre of the skinned carcasses muscle ran at an angle to the vertical axis 
rather than in line with it thereby minimizing the extent of shortening in the axial direction but the attendant heat induced rigour shortening in contralateral muscles probably accounted for the rearrangement of the skeletal structure, resulting in the sharp reduction in carcass, leg length as well as in breath of leg was experienced by singed and scalded carcasses in this study. The rib eye area was reduced in singed carcasses more than in scalded and skinned carcasss, this could be attributed to the attendant shortening of collage fibrils to as much as one third of their original lengths on heating. Since the collagen content of the skin is high, the heat on singeing could enhance shrinkage of the skin there by causing a tightening effect in the loin region there by inducing a reduction in the rib eye area in singed carcasses. The heat during flaming was probably sufficient to partially coagulate the muscle fibre protoplasm and effected decrease in fibre diameter according to Awosanya and Okubanjo (1993) and Okubanjo (1997).

\section{Carcass and primal cuts yield}

The yield or dressing percentage of a carcass is based on the clean carcass after the removal of external and internal offals, therefore, the fact that scalded carcasses furnished higher yield indicated that it could be due to the skin cover which might have added and increased the yield of the scalded and singed carcasses which was hitherto lacking in skinned carcasses, hence their low dressing percentage. In the same vein, the primal cuts yield were higher in scalded and singed carcasses, which could be as a result of skin cover in the two groups of dressed carcasses, while the skinned carcasses were lacking. This same reason was reported by Okubanjo (1997) and Omojola and Adesehinwa (2006).

\section{Physical characteristics of meat}

The most intensive and attractive colour was observed in singed meat followed by scalded meat and least in skinned meats. This could be adduced to heat applied which tended to stabilize myoglobin against the attack of oxidation, which could have affected the skinned meat since heat was not applied to the carcasses during dressing. Colour of meat is mainly been influenced by myoglobn $(\mathrm{mb})$ content and nature of meat as well as the compositional and physical state of muscle and meat structure (Cornforth, 1994), therefore because of myoglobin stabi- lity by heat meat from singed and scalded carcasses furnished most attractive meat samples. The presence and amount of intramuscular fat (marbling) in the body largely determine the specific gravity of any meat sample the result showed that specific gravity was higher in skinned meat indicating that skinned meat was less marbled than scalded and singed meat. Attah (1997) reported the carcass specific gravity provided the best prediction of beef carcass fat content as well as the best carcass lean content. In this study scalded carcasses had the least specific gravity probably due to high fat content confirming the report of Jones and Rompala (1984) that the higher the fat content of a carcass, the lower its specific gravity due to relatively low density of body fat compared with other tissues in the body. The cooking drip and cold losses as well as thermal and cold shortening were very high in singed meat due to the fact that there was general loss of fluid in form of juices whether during cooking, or drains or during refrigeration. The main intrinsic conditions that affect meat during cooking or refrigeration was that muscles structure got punctured by heat or pressure from refrigeration that led to draining of juices. Thermal shortening in the shrinkage observed in cooked meat which causes reduction in the initial length of a meat sample as well as cold shortening when meat in frozen, which could be due to physical shortening of collagen fibres to at least one third of their original length. The results obtained on cold shortening could also be due to moisture loss as a result of contraction in the meat that in related to release of calcium ions and the resultant muscle rigidity. The results obtained on cooking and drip losses, thermal and cold shortening are close to those reported by Fisher et al. (2000), Ukah et al. (2006), Dolatowski et al. (2000), Omojola (2008) and King et al. (2003). The results of Water Holding Capacity (WHC) showed that skinned meat held more water than either scalded or singed meat. It is the ability of muscle or meat to retain its naturally occuring water during application of any external fore and it is greatly infleunced by the solubility and state of myofibrillar and sarcoplasmic proteins (Dennis, 2002). There was a significant decrease in WHC in singed meat probably due to loss of fluids as a result of tightening of myofibrillar network by heat denaturation of proteins, while skinned meat was able to hold on to inherent water as no heat was applied to the carcasses (Omojola and Adesehinwa, 2006). The shearforce value was higher in singed and scalded meat. Shearforce measures the degree of toughness of meat and the higher value, the tougher is the meat (Omojola, 2008). The rapid development of 
heat induced contraction and rigid setting of muscle fibres during singeing could have accounted for toughness of singed meat according to Wheeler and Koohmariae (1994) and Okubanjo (1997).

\section{Proximate composition and $\mathrm{pH}$ of meat}

The results showed that skinned meat furnished higher moisture content than scalded and singed meat samples while singed meat furnished the least. This could be connected with loss of juices during singeing and scalding which involved flaming and pour of hot water on the carcasses that might have led to contraction of collagen and other tissues which forces fluids out of the carcasses. Protein was higher in singed meat probably due to coagulation of protein by heat according to Aduku and Olukosi (2000), who reported that when heat is applied to meat or during cooking protein coagulation occurs which makes protein available in the meat. As a result of skin cover, most of the subcutaneous fats were retained in the scalded carcasses hence, in the meat as shown in this study, while the reduction of fat in singed meat could be due to the fact that some of the fat might have melted and escaped during flawing of the carcasses. There was no significant difference in the ash content of meat across the treatments as well as the $\mathrm{pH}$ and it fell within the normal $\mathrm{pH}$ of fresh meat as reported by Sharma and Sharma (2011).

\section{Sarcomere length of muscles}

Skinned meat elicited the longest sarcomeres while the singed meat exhibited the least. This could be attributed to the effect of heat treatment of carcases. Sarcomeres are the structural units of muscle fibres which ensure the contractibility of muscles (Albrecht et al, 2006), therefore, their length could affect intramuscular connective tissues and greatly influence meat strucure or texture according to Wheeler et al. (2000) and Tschirhart-Hoelscher et al. (2006).

\section{Fibre diameter of muscles}

The results of fibre diameter showed similar trend with sarcomere length results of muscles. The skinned meat had higher values for fibre diameter in the primal cuts with loin eliciting the highest value for fibre diameter. The muscle fibres are long, narrow multinucleated cells that stretch from one end of muscle to the other and may attain a length of 34 $\mathrm{cm}$ or more, but are only $10-100 \mathrm{~cm}$ in diameter and differ from one muscle to another but influence meat quality. However, fibre diameter could be affected by treatment such as post-mortem dressing as observed in this study. Singeing had tremendous impact on the fibre diameter reducing them more than in scalding and skinning as reported by Okubanjo (1997), Tschirhart-Hoelscher et al, (2006) and Wheeler et al, (2000).

\section{Organoleptic characteristics of meat}

The taste panelists scored singed meat higher than either scalded or skinned meats probably because of its intensive colour, flavour, high tenderness and juiciness. Colour is the characteristic of visible radiant light with which an observer may distinguish differences between structures and is mainly influenced by myoglobin content of the meat, the composition and physical state of muscle (Cornforth, 1994). The flavor of singed meat was adjudged the highest; this could be due to the smoky flavour impacted on the meat by singeing process done with wood which might have transferred flavourful volatile acids in the smoke into the meat as well as the coagulation of protein in singed meat. Also, singed meat was rated higher for tenderness and juiciness due to the fact that heat applied to the carcasses might have ruptured the collagen and connective tissues of the muscle thereby rendering it more tenderer and the fact that protein higher in singed meat juiciness score was increased hence, higher acceptability score. The results obtained from this study sensory characteristics were close to those reported by Omojola and Adesehinwa (2006).

\section{CONCLUSION}

In conclusion, most of carcass characteristics such as high carcass weight, yield and rib eye area were favoured by scalding which could be of advantage to meat processors, but skinning furnished more advantages over scalding in terms of high carcass dimensions, cooking yield, water holding capacity, lower shearforce value, moisture content and texture which are very important as keeping quality of meat, while singeing the highest colour intensity, protein content and eating properties hence the highest acceptability. It is recommended therefore, that processors could adopt scalding for higher yield, and retailers could utilize skinning for keeping properties, while for the purpose of consumers preference singeing could be adopted for flavourful meat. 


\section{REFERENCES}

Aduku, A. O. and Olukosi, J. O. (2000): Animal Products Processing and Handling in the Tropics. Living Book Series, GU Publications, Abuja, Nigeria, pp 24-32.

Albrecht, E., Teuscher, F., Endr, K., Wagners, J. (2006): Growth and breed related changes of muscle bundle structure in cattle. J. Anim. Sci. 84, 2959-2964.

AMSA (2015): Research Guidelines for Cookery, Sensory Eevaluation and Instrumental Measurement of Fresh Meat. National Livestock and Meat Board, Chicago, IL, USA.

AOAC (2000): Official Methods of Analysis, 19 th $^{\text {th }}$ edition, AOAC International, Inc. Washington, D.C, pp. 12-19.

Apata, E. S. (2011). Quality attributes of Red Sokoto buck meat as influenced by post-slaughter processing methods. Ph.D. Thesis in the Department of Animal Science, University of Ibadan, Nigeria.

Attah, S. (1997): Live performance, carcass and offal characteristics of goats slaughtered at different weights. Ph.D. thesis, Department of Animal Science, University of Ibadan, Ibadan, Oyo State, Nigeria.

Awosanya, B. and Okubanjo, A. O. (1993): Effect of skinning, scalding or singeing on the physical characteristics of rabbit carcasses. Nig. Food Jour. 11, 147-152.

Cornforth, D. (1994): Colour - its basis and importance. In: Quality Attribute and Their Measurement in Poultry and Meat Products (A. M. Pearson and T. Rduston, Eds.) Advances in Meat Rresearch Book Series Vol. 9, Springer, Boston, pp. 34-78.

Dennis, I. S. (2002): Practical consideration of water holding capacity (WHC) measurement for processed meat: Pork quality measurement systems. Proc. of the Third Pork Quality Improvement Symp. AMSA, pp. 21-26.

Egbunike, G. N. and Okubanjo, A. O. (1999): Effects of processing upon the quality of Nigerian meat products. Livestoct Prod. Sci. 59, 155-163.

Fisher, P., Mellett, F. D. and Hoffman, I. C. (2000): Hallothane genotype and pork quality: Carcass and meat quality characteristics of three halothane genotype. Meat Sci. 54 (2), 97-105.

Insausti, K., Beriam, M. J., Purroy, A., Alberti, P., Gorraiz, C., Alzueta, M. J. (2001): Shelf life of beef from local Spanish cattle breed stored under modified atmosphere. Meat Sci. 57, 273-281.

Jones, S. D. M., Rompala, R. E. (1984): A comparison of specific gravity and carcass measurement as predictors of beef carcass composition. Can. J. Anim. Sci. 50, 31-41.

Keith, E., Belk, J. A., Scanga, G. C., Grandin, T. (2002): The relationship between good handling/ stunning and meat quality in beef, pork and lamb. Ame: Meat Institute Foundation (AMIF) Animal Handling and Stunning Conference 21-22, USA, pp 1-19.

King, D. A., Dikeman, M. E., Wheeler, T. L., Koohmariae, M. (2003): Chilling and cooking rate effect on some myofibrillar determinants of tenderness of beef (Measurements of cold shortening in frozen meat), J. Anim. Sci. 81,1473-1481.

Koohmariae, M. (1996): Biochemical factors regulating the toughening and tenderization of meat processes. Meat Sci. 43, 5193-5201.

Lawrie, R. A., Ledwards, D. A. (2006): Lawrie Meat Science $7^{\text {th }}$ (ed), Cambridge Woodhead Publishng Limited, UK. pp. 157-160.

Mactin, C; Balcarzak, D., Tillay, R., Deldays, M. (2003): Determinants of meat quality tenderness. Proc. of the Nutriation Society, 62, 337-347.
Maiga, A. M. (1974): Physical and chemical composition of the carcass of domestic bovineas influenced by breed, sex, level of feed intake and stage of growth. Ph.D. thesis, University Ithaca, New York, USA.

Maize, A.M. (1974): Physical and chemical composition of the carcass of domestic bovine as influenced by breed, sex, level of feed intake and stage of growth. Ph.D. thesis, Cornell University Ithaca. N.Y, USA.

Mallikarjuman P. and Mittal, G. S. (1994): Meat quality attributes during beef carcass chilling. J. Food Sci. 59, 291-294.

Marchiori, A. F. and DeFelicio, P. E. (2003). Quality of wild boar meat and commercial pork. Sci. Agric. (Piracicaba, Braz.), 60 (1), 1-10.

McMillan, K. W. and Brock, A. P. (2005): Production practice and processing for value added goat meat J. Anim. Sci. 83, E57-E68.

Monin, G., Talmant, A., Aillery, P., Collas, G. (1995): Effects of carcasss weight and meat quality of pigs delicured by scalding or singeing post-mortem. Meat Sci. 39, 247-254.

Okubanjo, A. O. (1997): Meat characteristics of singed and conventionally dressed chevon carcasses. J. Food Sci. \& Technol. 34 (6), 494-497.

Okubanjo, A. O., Omojola, A. B.; Ogunsola, O. O. Adewunmi, M. K., Ajiboro, O. G., Alabi, G. F., Babayemi, O. J. (2003): Meat characteristics of Bunaji, Gudali and Keteku cattle. Trop. Anim. Prod. Invest. 6,: 185-193.

Omojola, A. B. and Adesehinwa, A. O. K. (2006): Meat characteristics of scalded, singed and conventionally dressed rabbit carcasses. World J. Zool. 1 (1), 24-29.

Omojola, A. B. (2008): Yield and organoleptic characteristicies of Suya (an intermediate moisture meat) prepared from three different muscles of mature bull. African Journal of Biotechnology, 7 (13), 2254-2257.

Qiaofen, C. and Da-Wen, S. (2005): Application of PLSR in correlating physical and chemical properties of pork ham with different cooking methods. Meat Sci. 70, 691-698.

SAS (2002) Statistically Analysis System. SAS stat version 9 SAS institute Inc. Garrry NC, USA.

Sharma, B. D., Sharma, K. (2011): Outlines of Meat Science and Technology. JayPee Brothers Medical Publisher (P) Ltd. New Delhi, India. pp 348-364.

Sobecak, M., Lachowicz, K., Kamieniecki, H., Wojcik, J., Gajowiecki, L., Żochowska J., Życha, A., Kotowicz, M., Sablik, P., Rzewucka, E. (2005): The effect of cattle genotype on texture of selected muscles during post-mortem ageing. Electronic Journal of Polish Agricultural Universities. Series Food Science and Technology, 8 (1), 1-9.

Tschirhart-Hoclscher, T. E., Baird, B. E., King, D. A., Mckena, D. R., Savall, J. W. (2006): Physical, chemical and histological characteristic of 18 lamb muscles. Meat Sci. 73: $48-54$.

Ukah, O. G., Omojola, A. B., Ogunsola, O. O., Okubanjo, A. O. (2006): Carcass and meat characteristics of grass cutter (Thryonomys swinderianus). Trop. J. Anim. Sci. 9 (1), 3138.

USDA (1997): Official United States Standard for grades of carcass beef. U.S. Department of Agriculture, Consumers and Marketing Service, Washington, D. C, USA.

Wheeler, T.L. and Koohmariae, M. (1994): Pre-vigor and Postvigor changes in tenderness of ovine longissimus muscle. J. Anim. Sci. 72 (5), 1232-1238.

Wheeler, T.L., Shackelford, S. D. and Koohmariae, M. (2000): Variation in proteolysis, sarcomere length, collagen content and tenderness among pork muscle. J. Anim. Sci. 78, 958-965. 